\title{
Vulvar Cancer pN1b TNM Finding v7
}

National Cancer Institute

\section{Source}

National Cancer Institute. Vulvar Cancer pN1b TNM Finding v7. NCI Thesaurus. Code C89432.

Vulvar cancer with one lymph node metastasis measuring $5 \mathrm{~mm}$ or greater. (from AJCC 7th Ed.) 